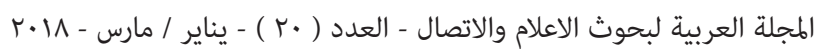

\title{
Attitudes of Teachers toward Media Education in Saudi Arabia
}

\section{Dr. Hanan Ahmed Ashi}

Associate professor, King Abdulaziz University at King

Abdul Aziz University

\section{Abstract:}

Media education is an essential part of modern education as it protects children and youth from the risks and negative effects of media. This exploratory study primarily seeks to describe what teachers believe, think, or understand (attitudes) regarding their students' involvement with popular electronic media and then assess the impact of media education on teachers. The study used a purposive sample of 121 teachers involved in basic education, and collected data using a questionnaire and discussion. Basic education teachers were recruited for the questionnaire survey and discussion sessions to determine the teachers' perceptions of the number of hours that students spend on media, the extent and type of media's negative effects, and the teachers' own manner of responding to such media use. After exposure to a media education program, $94.3 \%$ of the teachers expressed inclination toward implementing media education for students. The study recommends that basic education should utilize learning environments consistent with the real-world situations faced by students, supplemented by teachers' understanding and openness. 


\section{Introduction}

The world has witnessed radical changes in the field of information and communication, culminating in the merging of computer technologies and communication techniques. A result of this scientific and technological shift was the emergence of what is known as the information society, in which information is the primary and strategic resource (Yahia 2012). Most societies today are witnessing a conflict between popular electronic media and educational goals. The existing educational system is based on a disciplined system of values, achievement, and uniqueness of education; meanwhile, the information system is based on mass communication, which focuses on the new and on providing fun and entertainment that is easy to understand regardless of the methods, content, and language used (Almalik 2014). The recreational nature of mass communication techniques appears to be in direct conflict with the basic principles of the educational system. This conflict thus can be seen as one between school culture and media culture (Aldilami 2012).

The question that arises then is who will fulfill the traditional responsibilities of the teacher in this changing scenario. In addition to providing education, the teacher is also a moral educator who instills the values of society in the younger generation to shape them into responsible members of society (Al-Fayez 2009). The concept of media education (ME) can be seen as an attempt at fulfilling the role of the traditional teacher (Al-Shimamri 2010). ME has emerged as an immunization attempt to protect children and youth by empowering them to detect, reject, and overcome fraudulent media messages and inappropriate values (Al-Bitar 2009). ME develops critical analysis skills that help students filter and evaluate the overwhelming amount of information that invades their lives (Al-Shimamri 2010).

\subsection{Education in Arab World}

Several studies, which are conducted in the different Arab countries, refer to the low level of education quality. This because the education system depends on memorizing techniques, which leads to weak abilities inside the mind and personality of the student. To improve the education level quality, we have to focus on building the required abilities and skills such as the analysis, induction, application skills.

The annual report published by the Word Bank in 2007 about the development in the Arab World, showed to the percentage of the enrolled females in the primary education was increased. In addition, the report stated that about $5 \%$ of the national income and about $20 \%$ of the government expenditure was spent on education during the last 40 years (World Bank Report 2007).

\subsection{Education in Saudi Arabia}

The first education system in the Kingdom of Saudi Arabia started by the establishment of the Directorate of Knowledge in 1925. It was the keystone for the boys' education system in the kingdom. In 1927, the first Council of Knowledge was established to monitor the education in the Hijaz region. Upon 
المجلة العربية لبحوث الاعلام والاتصال - العدد ( •r ) - يناير / مارس - \ا•r

the establishment of the Kingdom of Saudi Arabia (KSA), the function of the Directorate of Knowledge was extended to monitor the education system in the whole kingdom. It started by only 4 schools in the Hijaz region, but then increased to 323 schools by the end of 1927. In the Reign of King Saud Bin AbdulAziz Al-Saud, the Ministry of Knowledge was established in 1951 as an extension to the Directorate of Knowledge. King Fahd Bin Abdul-Aziz Al-Saud was the first Minster of Knowledge to monitor the boys' education system in the different general education schools that include Primary, Preparatory and Secondary schools. In 1960, the General Presidency of Girl's Education was established to be responsible for girls' primary schools in the kingdom in addition to one female teachers' intermediate institute. It was added to the Ministry of Knowledge in 2002 by a Royal decree (Ministry of Education 2017).

The education system in the Kingdom of Saudi Arabia is considered one of the basic pillars that holds that social system. The Islamic Shariaa reserves the right for education for each citizen that is guaranteed by the government. The Higher Committee for the Education Policy in the Kingdom of Saudi Arabia in 1970 published the Education Policy Document that is considered the basic reference for the education system. This document contains several principles such as preserving the Islamic identity, and separating between the female and male students in all the education programs (Abo-Arrad 2004). According to the education system in the
Kingdom of Saudi Arabia, the male schools are separated from the female schools in all levels of education. This may present Saudi teachers with different cultural and behavioral issues. In order to be able to teach in the Saudi schools, the teachers must complete at least 4 years study in university.

The Organization of Economic Co-operation and Development (OECD) published a report entitled "Universal Basic Skills: What Countries Stand to Gain" in May 2015. In this report, the countries were ranked based on the performance of the students in the mathematics and science subjects. The report stated that the Kingdom of Saudi Arabia came in the $66^{\text {th }}$ rank between the world countries and ranked in the $6^{\text {th }}$ place within the Arab countries. This showed that the Kingdom of Saudi Arabia faces many problems in the general education system (Hanushek \& Woessmann 2015).

The Kingdom of Saudi Arabia on its future directives aims at facing many challenges. The main challenge is to activate the education role in building the right personality of the citizens. The improvement in the mass communication means and its worldwide spread requires complete preparation from the educational and cultural organizations to benefit from the new technology outputs in order to return to the society with more benefits without harming its principles and morals. They are responsible for providing the students with morals, knowledge, and behavior to protect them from the dangerous deviations. As a conclusion, the role of the educational institutes is not only providing students with knowledge and 
facts but also learning the skills, thinking techniques, right attitudes and morals and moderate behavior (Dehish 2013).

\subsection{Media Education in Saudi Arabia}

Before we talk about the media education in Saudi Arabia, we should present what is meant by it first. Bukingham (2003) defined Media Education (ME) as "the process of teaching and learning about the media". There are several versions of this definition but all share the concept of how the individuals can deal with the media in different ways. For example, the US National Association for Media Literacy Education (NAMLE, 2010) defined media literacy as a series of communication competencies with different tasks, including the ability to access, analyze, evaluate, and communicate information in a variety of forms. In UK, Ofcom (2010) had a similar definition for media literacy. It is defined as "The ability to access, understand and create communications in a variety of contexts". Media Literacy Week (2010) in Canada had another definition, which is "Media education is the process through which individuals become media literate-able to critically understand the nature, techniques and impacts of media messages and productions".

Since 1960s, a new educational subject for media education has been emerged in the US schools to study the theories, criticisms and debates about mass media in order to promote media literacy (Lee 2010). In the past decade, advanced media techniques have changed the social norms and values in Western society, with impacts likewise spreading widely to other societies worldwide, posing a threat to their social and cultural values (Aldilami 2013; Zhang et al. 2014). Saudi Arabia, the center of Islam and a symbol for Muslims and Muslim societies worldwide, is particularly apprehensive of this phenomenon. Specifically of interest to this study, educators in Saudi Arabia are highly concerned about protecting Islamic identity (Ministry of Education 2016).

To spread the culture of Media Education in Asia and Gulf region, the Kingdom of Saudi Arabia was in the lead by organizing the First International Conference on Media Education in Riyadh 2007 under the generous patronage of King Abdullah Bin Abdul-Aziz Al-Saud. Around 3000 participants from all over the world attended the conference to share their research ideas, models, and suggestions in the area of media education. The Ministry of Education organized this conference with collaboration with the International Organization for Media Education, The United Nations Educational, Scientific and Cultural Organization (UNESCO), University of Barcelona and the Arab Bureau of Education in the Gulf States. In conjunction with the conference program, many specialized workshops and seminars were held in addition to an exhibition for communication and media technologies. The conference conclusions had several recommendations; we will highlight some of them. The interest of the concept of media education should be in all the different education levels. It also suggested that the Ministry of Education should plan and prepare a complete media education course to be taught in the higher education institutes. 
المجلة العربية لبحوث الاعلام والاتصال - العدد ( •r ) - يناير / مارس - \ا•r

Another recommendation from the conference was to start to build specific plans and programs for media education with complete preservation of religious, national, moral and ethical values. The conference also recommended that the educational organization in both the public and private sectors should encourage the scientific initiatives related to the media education and benefit from the different international experiments in the different media education fields.

Schoolteachers have different reactions to the rising popularity of electronic media, with their focus on protecting the country's religious and cultural fabric. On the one hand, many encourage children to adopt self-censorship, and on the other hand, there are those who push for increasing the number of topics covered in basic education curricula to protect students from the harmful effects of electronic media (AlOqaili 2015). These differences in thinking and attitudes among teachers toward media create a sense of confusion in young minds, which tend to be attracted to exploring newly available media (Aldilami 2012; Doha Centre for Media Freedom 2012). Therefore, teachers need to adopt a common strategy to deal effectively with the negative effects of electronic media.

\subsection{Previous Studies}

A brief review of a few relevant studies in the field of implementing ME in primary schools shows that liberal countries have made major advancements compared with non-liberal or authoritarian ones, such as the Arab states and China.
Deal et al. (2010) assessed a media education program during a full semester in one American school. In interviewing teachers who integrated an ME syllabus in the provided curricula, they found a link between the interpretation of media knowledge, past experiences, and personal values. Meanwhile, Pinkleton et al. (2008) studied the impact of the school curricula on the awareness of students in terms of their understanding of and resistance to the influence of media on their decisions concerning sexual relationships. The study emphasized the teacher's role in explaining educational content to the students. The study by Hobbs (2005) on students in Pennsylvania identified the reasons for the variety in students' interpretation and understanding of media messages and clarified the role of teachers in public schools. The study conducted in-depth interviews with a group of scientists, educators, media professionals, and teachers, and ultimately recommended integrating media education with the school curricula.

Meanwhile, in China, Zhang et al. (2014) conducted a survey of 392 primary school teachers to investigate media literacy education (MLE) and its integration in Chinese primary schools, focusing on the level of concerns of Chinese teachers and teacher practices in the integration process. They found that MLE integration was significantly related to the level of teachers' personal concerns and their perceived need for MLE.

In the context of the Arab world, research on ME has been scarce and outdated. Akhdar (2007) studied Saudi teachers' exposure 
to media and the repercussions of media consumption on young people. The study used an analytical method to monitor how both education and information can be combined to achieve common goals. It recommended the establishment of a committee of educators and media professionals to discuss strategies for planning these issues and defining goals.

The Doha Centre for Media Freedom (2012) conducted a study to assess the awareness of teachers from 15 Qatari schools on the techniques, skills, and terminology used in media contents. The teachers were able to report students' favorite media, especially YouTube, Facebook, and other social networks. The study recommended the expansion of ME programs to include all of the stakeholders in the educational process-students, teachers, and educational policy makers - and the use of social media networks to attract the interest of students.

To the best of the author's knowledge, studies specifically related to the roles and attitudes of teachers toward ME applications are rare or non-existent in the Arab world in general and Saudi Arabia in particular, which justifies the need for this study. This exploratory research is the first of its kind in Saudi Arabia. It considers the intensive and indiscriminate use of new mass media communication tools, particularly among children in Saudi Arabia (Ashi 2007; Deal et al. 2010), and adheres to the view of emphasizing the role of the teacher in the implementation of ME. In studying the impact of communication technology in the absence of effective protective mechanisms, this work gains a community dimension. Specifically, the study primarily seeks to describe what teachers believe, think, or understand (attitude) regarding their students' involvement with popular electronic media, and then assess the impact of media education on teachers.

\section{Methodology}

The study uses an analytical descriptive method to measure and describe teachers' understanding of their students' involvement in media activities. A qualitative analysis was subsequently performed for assessing the impact of ME exposure on teachers.

\subsection{Sample}

The study used purposive sampling to recruit 121 teachers in elementary and middle school (male $=76$, female $=45)$ involved in basic education and who were willing to participate in the research. Their participation helped them obtain an additional certificate of experience from their schools. The study was approved by board and consent was obtained from the principals.

\subsection{Research questions}

The study operationalized the research objectives by formulating the following research questions:

Question 1: How much time do teachers think students spend on media activities?

Question 2: What is the extent of the negative effect of media consumption on students according to teachers?

Question 3: What are the types of negative 
المجلة العربية لبحوث الاعلام والاتصال - العدد ( •r ) - يناير / مارس - \ا•r

effects of media consumption on students according to teachers?

Question 4: How do teachers respond to the negative effects of media consumption on their students?

Question 5: What is the impact of ME exposure onteachers?

\subsection{Data collection tools}

A questionnaire was designed to elicit responses to the five questions. Face validity of the questionnaire was assumed, as the study was exploratory and the research questions were direct and simple. To assess the impact of $\mathrm{ME}$, teachers were introduced to the training kit (Media Education Portfolio for Teachers) prepared by the Media Education Research Team of the Scientific Endowment at University, supervised by. The participants were then asked about their inclination to implement ME.

\subsection{Statistical analysis}

SPSS 20.0 was used to generate descriptive (frequencies, percentages, averages) statistical information on the quantitative data obtained using the questionnaire. A qualitative analysis of the outcome of discussion groups was undertaken by categorizing the different responses.

\section{Results and Discussion}

Table 1 shows the response to Question 1on the time that teachers think their students spend with popular media. Most teachers (74.4\%) thought that students spend more than two hours, whereas nearly a quarter of the respondents
$(23 \%)$ thought that students spend one to two hours. The teachers considered their students' involvement with electronic media activities as intensive.

Table 1. Teachers' views on the time spent on media by students

\begin{tabular}{lll}
\hline Intensity of use & Frequency & $\mathbf{( \% )}$ \\
\hline More than 2 hours & 90 & 74.4 \\
1 to 2 hours & 28 & 23.1 \\
Less than an hour & 3 & 2.5 \\
Total & 121 & 100 \\
\hline
\end{tabular}

Table 2 indicates the responses to Question 2 on the teachers' perception of the extent of negative effects of the media on their students. The teachers strongly believed that electronic media use has serious negative effects, with $85.1 \%$ indicating such effects to be "extremely strong."

Table 2. Teachers' views on the extent of the negative effects of electronic media exposure on students

\begin{tabular}{lll}
\hline Degree of negative effect & Frequency & $\mathbf{( \% )}$ \\
\hline Significant effect & 103 & 85.1 \\
Some effect & 14 & 11.6 \\
No effect & 3 & 2.5 \\
Don't know & 1 & 0.8 \\
Total & 121 & 100 \\
\hline
\end{tabular}

As regards the types of negative effect (Table 3) in response to Question 3, the teachers identified three major behavioral problems they 
attributed to media exposure: indulgence in excessive fantasy $(70.2 \%)$, artificiality of values (49.6\%), and violence $(46.3 \%)$. This ranking indicates that teachers believed behavioral problems among their students to be due to popular media.

Table 3. Teacher's views on the types of negative effects of electronic media use on students

\begin{tabular}{llccccc}
\hline Rank & Type of negative impact & Yes & $\%$ & No & $\%$ & Total \\
\hline 1 & Indulgence in Excessive Fantasy & 85 & 70.2 & 36 & 29.8 & $100 \%$ \\
2 & Artificiality of values & 60 & 49.6 & 61 & 50.4 & $100 \%$ \\
3 & Violence & 56 & 46.3 & 65 & 53.7 & $100 \%$ \\
\hline
\end{tabular}

Table 4 indicates the responses to Question 4 , on the teachers' manner of response to the negative effects mentioned above. Most of the teachers $(64.5 \%)$ reported imposing strict rules and prohibitions related to media use, whereas a third of the respondents $(31.4 \%)$ mentioned talking with students as their preferred approach. These above findings clearly indicate that teachers tend to prefer to adopt a stringent or uncompromising attitude toward the issue of media use among students. This could perhaps be attributed to the rigidity in the thinking of schoolteachers. It may also indicate a genuine lack of knowledge, if not ignorance, regarding $\mathrm{ME}$ as an effective means of mitigating the negative effects of electronic media exposure.
Table 4. Teachers' views on the types of response to the negative effects of electronic media exposure on students

\begin{tabular}{lll}
\hline Response & Frequency & $\mathbf{( \% )}$ \\
\hline Rules and regulations & 68 & 64.5 \\
Dialogue and discussion & 38 & 31.4 \\
Anger and punishment & 8 & 6.6 \\
Does not concern me & 5 & 4.1 \\
Powerless & 2 & 1.65 \\
\hline Total & $\mathbf{1 2 1}$ & $\mathbf{1 0 0}$ \\
\hline
\end{tabular}

The above finding logically leads to Question 5 on acquainting the sample teachers with ME. The sample was reduced to 105 from 121; not all of the teachers could complete the ME program. Discussions on ME were conducted to assess its impact on teachers. A majority (94\%) expressed their satisfaction and inclination to implement ME, whereas a small minority $(6 \%)$ expressed resistance to the concept.

Table 5. Impact of ME exposure on teachers

\begin{tabular}{lll}
\hline Inclination to implement ME & Frequency & $\mathbf{( \% )}$ \\
\hline Yes & 99 & 94.3 \\
No & 6 & 5.7 \\
Total & 105 & 100 \\
\hline
\end{tabular}

\section{Conclusions}

This exploratory study, the first of its kind in Saudi Arabia, has more or less achieved its objective by proving that Saudi teachers' attitude toward popular media either emerges from their ignorance of the effectiveness of ME or their own personal values, but that once exposed to ME, 
المجلة العربية لبحوث الاعلام والاتصال - العدد ( •r ) - يناير / مارس - \ا•r

they were highly interested in implementing it. Various culture-specific recommendations have been proposed by researchers to spread awareness of ME and create a media-literate society. The Doha Centre for Media Freedom (2012) recommended the expansion of $\mathrm{ME}$ programs to include all stakeholders - students, teachers, educational policy makers-in the educational process and the use of social media networks to attract the interest of students. Hobbs (2005) suggested integrating ME in the school curricula, whereas Akhdar (2007) recommended establishing a committee of educators and media professionals to discuss strategies for planning and setting goals.

The present study recommends the need to transform basic education into a learning environment consistent with the real-world situations faced by students, complemented by the active support of teachers through adopting an understanding and open demeanor. This research proposes the inclusion of all stakeholders-students, teachers, parents, educational policymakers/administrators, media practitioners, and social workers-in ME programs.

\section{Compliance with Ethical Standards}

Conflict of Interest: The authors declare that they have no conflict of interest.

Research involving Human Participants and/or Animals: The study was approved by the board.

Informed consent: Informed consent was obtained from the principals.

\section{References}

Abo-Arrad, S. (2004). The Educational System in the Kingdom of Saudi Arabia and the Globalization Challenges. Presented at the Globalization and Education Priorities, Faculty of Education, King Saud University, Riyadh. (In Arabic).

Al-Fayez, F. (2009). The role of educator in student education. Arabic Library. http://arablib. com

RrM3Ep\&rand2=cG5PaFJHNVUqMG1C) (In Arabic). Accessed 25 November 2015.

Akhdar, F. (2007). Teachers' exposure to the media and its impact on young people. KSA, Riyadh: The First International Media Education Conference.

Al-Bitar, L. (2009, October). The concept of media education in books of civic and national basic education in Palestinian curriculum. Paper presented at Conference of educational process in the 21st century: Realities and challenges, AnNajah National University.

Aldilami, A. (2012). Media and Children. Amman: Dar Al Maseera.

Aldilami, A. (2013). Islamic Media. Amman: Dar Al Maseera.

Almalik, K. (2014). Between media and education. Al-jazirah.com Newspaper. www. al-jazirah.com/2014/20140323/mh2.htm (In Arabic). Accessed 12 October 2015.

Al-oqaili, B. (2015). ME in the face of negative media. www.hbthedu.gov.sa/art/s/10 (In Arabic). Accessed 3 June 2016.

Al-Shimamri, F. (2010). Media education: How to deal with media? http://www. saudimediaeducation.org/media book/pdf/ media book.pdf (In Arabic). Accessed 22 January 2017.

Ashi, H. (2007). Developing skills of 
interaction with the screen in Saudi families. In U. Carlsson, S. Tayie, G. Jacquinot-Delaunay, \& J. Tornero (Eds.), Empowerment through media education: An intercultural dialogue (pp. 211223). Goteborg University, Sweden: The International Clearinghouse on Children, Youth and Media, Nordicom, in cooperation with UNESCO, Dar Graphit, and Mentor Association.

Buckingham, D. (2003). Media education: Literacy, learning and contemporary culture. Cambridge: Polity.

Deal, D., Flores-Koulish, S., \& Sears, J. (2010). Media literacy teacher talk: Interpretation, value, and implementation. Journal of Media Literacy Education, 1(2), 121-131.

Dehish, K. (2013). Foresight the Future of Education in the Kingdom: The Present and Future. Technical Report, Ministry of Education, Kingdom of Saudi Arabia. (In Arabic).

Doha Centre for Media Freedom. (2012). Program of media education. www.dc4mf.org/ ar/content/1301 (In Arabic). Accessed 7 October 2014.

Hanushek E. \& Woessmann, L. (2015). Universal Basic Skills: What Countries Stand to Gain, OECD Publishing, Paris. DOI: http:// dx.doi.org/10.1787/9789264234833-en

Hobbs, R. (2005). Strengthening media education in the twenty-first century: Opportunities for the state of Pennsylvania. Arts Education Policy Review, 106(4), 13-23. Lee, A. Y.L. (2010). Media Education: Definitions, Approaches and Development around the Globe. New Horizons in Education, 58(3), 1-13.

Media Literacy Week (2010). What is Media Education? (Website for Media Literacy Week). http://www.medialiteracyweek.ca/about/whatis-media-education/. Accessed 5 June 2017.
Ministry of Education. (2016). General bases of education in Saudi Arabia. www.moe.gov. sa/ar/PublicEducation/ResidentsAndVisitors/ Pages/TheGeneralPrinciples.aspx (In Arabic). Accessed 17 December 2016.

Ministry of Education. (2017). Establishment of the Ministry of Education. Available at: https:// www.moe.gov.sa/en/TheMinistry/Education/ Pages/EstablishmentoftheMinistryofEducation. aspx. Accessed 15 June 2017.

NAMLE (2010). Media literacy defined. Namle.net (website for National Association for media Literacy Education). Retrieved September 11, 2010, from http://namle.net/ publications/ media-literacy-definitions.

Ofcom (2010). What is media literacy Ofcom's definition. Ofcom.org.uk (website for Ofcom). Retrieved September 15, 2010, from http://stakeholders.ofcom.org.uk/marketdataresearch/media-literacy/about/

Pinkleton, B., Austin, E., Cohen, M., Chen, Y., \& Fitzgerald, E. (2008). Effects of a peer-led media literacy curriculum on adolescents, knowledge and attitudes toward sexual behavior and media portrayals of sex. Health Communication, 23(5), 462-472.

The World Bank. (2007). Development Report in Middle East and North Africa. Available at: www.worldbank.org. Accessed 10 May 2017.

Yahia, I. B. (2012). The world of technology. www.tech-wd.com/wd/arab-ict-use-report-2012 (In Arabic). Accessed 3 May 2014.

Zhang, H., Zhu, C., \& Sang, G. (2014). Teachers' stages of concern for media literacy education and the integration of MLE in Chinese primary schools. Asia Pacific Education Review, 15(3), 459-471. 